\title{
Hand-Rearing of Rabbits Using Rabbit Milk and Commercial Milk Powder, Teo Milk ${ }^{\circledR}$
}

\author{
Masao AKUZAWA, Naochika MATSUNUMA and Yoshio SUZUKI \\ Laboratory Animal Science and Toxicology \\ Laboratories, Sankyo, Co., Ltd. \\ Horikoshi, 717 Fukuroi, Shizuoka 437
}

(Received for publication: March 29, 1978)

\begin{abstract}
Caesarean-derived Japanese White rabbits were raised by hand-feeding till 9 days after birth with rabbit milk and from 10 days till weaning with mixture of rabbit milk and commercial milk diet for dogs and cats, Teo milk ${ }^{\circledR}$ (SANKYO Co. Ltd.). They showed good growth with $78 \%$ of weaning at 5 weeks of age and $63 \%$ of raising at 6 months of age.
\end{abstract}

\section{ウサギ乳と市販イヌネコ用粉乳 Teo milk ${ }^{\circledR}$ によるウサギの人工哺育}

阿久沢正夫・松沼尚史 · 鈴木善雄

ウサギの人工哺育は, ウサギ乳 [1] あるいは人工乳 $[3$, 7]を用いておこなら方法が報告されている。両者はそ れぞれ一長一短があって, ウサギ乳は成長は良いが入手 がやや困難であり，人工乳はウサギ乳とくらべて成長が やや劣り [9]，またウサギが好んで飲まない場合もある [1]といわれる。著者らは生後初めはウサギ乳だけ，途 中からウサギ乳と市販イヌネコ用粉乳を用いて調製した 人工乳を混合して与え, 両者の短所を補い合うようにし てウサギの人工哺育をおこなったが，一応の成果が得ら れたのでここに発表する。

1. 乳汁：ウサギ乳は conventional 飼育の授乳中の ウサギから搾った。泌乳量は分娭後の日数, あるいは個 体などにより差はあったが, 夕方哺乳仔を離して翌朝撨

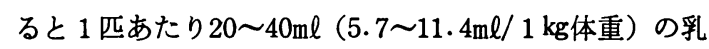

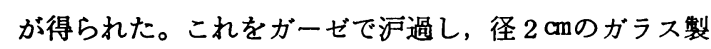
試験管に注入後アルミ箔で蓋をし, 沸騰水中に 3 分間浸 漬後流水で急冷し, $0 \sim 10^{\circ} \mathrm{C}$ の冷蔵庫に保存した。こ
の加熱処理だけで 1 週間以上色, 臭などに変化はみられ なかったが，実際には㩁乳後24時間以内に使用した。

人工乳は, Table 1 の組成をもつ市販イヌネコ用粉 乳（テォミルク, 三共株式会社）を用いて, 温湯 $15 \mathrm{~m} l に$ 粉乳 $6 \mathrm{~g}$ の割合で溶解し調製した。

2. 供試ウサギ : conventional 飼育の日本白色種ウ サギを用いた。妊娠30日令のときに耳静脈内に空気を注 入と殺し, 直ちに子宮を摘出した。子宮は約 $42^{\circ} \mathrm{C}$ に保 った 1,000 倍逆性石けん液（ハイアミン, 三共株式会社） に浸漬し, 消毒液内で切開した。子宮から摘出した胎仔 は，消毒液から出したのちに胎膜を切開した。

3. 飼育環境：人工哺育および離乳後の飼育をおこな った棟は, 内部の空気の滅菌はとくにおこなわなかっ た。作業員は棟内専用の衣類, はきものを着用し, また 入棟時に手指を消毒した。

飼育に用いたケージは，20日令まではプラスチック製 ラットケージ $(300 \mathrm{~mm} \times 355 \times 175)$ で, タオルを敷い 
Table 1. Composition of commercial diet, Teo milk®

\begin{tabular}{lr}
\hline Crude protein & $33.6 \%$ \\
Crude fat & $39.3 \%$ \\
Lactose & $18.9 \%$ \\
Moisture & $2.0 \%$ \\
Ash & $6.2 \%$ \\
& \\
Vitamins (per 100 grams) & \\
Vitamin $\mathrm{A}$ & $10,000 \mathrm{I} . \mathrm{U}$. \\
Vitamin $\mathrm{D}_{2}$ & $800 \mathrm{I} . \mathrm{U}$. \\
Vitamin $\mathrm{B}_{1}$ & $0.3 \mathrm{mg}$ \\
Vitamin $\mathrm{B}_{2}$ & $3.0 \mathrm{mg}$ \\
Vitamin $\mathrm{B}_{6}$ & $0.1 \mathrm{mg}$ \\
Vitamin $\mathrm{B}_{12}$ & $4.0 \mu \mathrm{g}$ \\
Niacin & $4.0 \mathrm{mg}$ \\
Pantothenic acid & $1.5 \mathrm{mg}$ \\
Folic acid & $10 \mu \mathrm{g}$ \\
Choline chloride & $300 \mathrm{mg}$ \\
\hline
\end{tabular}

て使用した。タオルは1日 1 回交換した。21日令からは 通常のアルミ製ウサギケージ $(450 \mathrm{~mm} \times 400 \times 400 ）$ に 移し，60日令までは 1 ケージあたり $2 \sim 3$ 匹，それ以後 は個別に飼育した。

飼育温度は, 20 日令をでは 1$)$ 室温を $27 \pm 2{ }^{\circ} \mathrm{C}$ とす る，2）室温を $22 \pm 2{ }^{\circ} \mathrm{C}$ とし, 補助熱源として養豚用 マットヒーター（東京芝浦電気株式会社）をケージの下 に置いて床温度を $40 \pm 3{ }^{\circ} \mathrm{C}$ に保つ，の 2 条件を設定し た。21日令以後はすべて室温 $22 \pm 2{ }^{\circ} \mathrm{C}$ として, 補助熱 源は用いなかった。

4. 哺乳器具と哺乳：4〜5 日令までは乳児用栄養力 テーテル（アトム株式会社）のビニールチューブを切除 し，注射筒に装着するアダプターの部分を乳首とした (アダプターは注射筒に装着)。注射筒にいれた乳汁を仔 ウサギの吸ら速さに合わせて押し出した。成長して吸ら カが強くなってからは，小動物用哺乳びん（グビ一哺乳 びん本舗）を用いた。しかし摘出時体重が $50 \mathrm{~g}$ 以上で充 分に大きく, また乳を吸ら力も強い仔ウサギは, 摘出後 すぐに哺乳びんから飲ませた。乳汁は $42^{\circ} \mathrm{C}$ に温めて与 えた。

授乳は摘出した翌日から始めたが，9 日令時頃までは 授乳量が少ないためにウサギ乳だけ，また10日令時以後 はウサギ乳と人工乳を 1：1に混合し（以下混合乳と略 す）与えた。

授乳回数は Bernard [2] による1日 1 回よりも2回 としたほらが死亡率が低いとの報告を参考として，19日
令時までは 1 日 2 回（午前 9 時, 午後 3 時 30 分）とし, 20 日令時以後は離乳準備のため 1 日 1 回（午前 9 時）と した。

仔ウサギには，注射筒から押し出した乳汁を吸引しな くなるまで, あるいは哺乳びんの乳首をロから離すまで 授乳した。その結果授乳量は 1 日令の $3 \sim 5 \mathrm{~m} \ell$ (約 $9 \mathrm{~m} \ell$ $/ 100 \mathrm{~g}$ 体重）から漸増し， 7 日令で $13 \mathrm{~m} \ell （$ 約 $21 \mathrm{~m} \ell / 100 \mathrm{~g}$ 体重), 14 日令で $24 \mathrm{~m} \ell$ (約 $19 \mathrm{~m} \ell / 100 \mathrm{~g}$ 体重) であった。

5. 離乳：21日令時頃から授乳回数を減らすとともに, ウサギ用固型飼料（R C-4, オリエンタル醅母工業株式 会社）と水を滅菌せずに与えはじめた。体重が $300 \mathrm{~g}$ を こえ，拱慨していることが認められ，また数日間授乳し なくても体重が毎日増加したとき，授乳を完 全にやめ た。これはほぼ30日令であった。

6. 離乳率と育成率 : 4 匹の種親から摘出した 32 匹を 人工哺育したが， 5 週令までの生存仔数は $25 匹 （$ 離乳率 $78 \%$ ）また 6 ケ月令までの生存仔数は 20 匹（育成率 63 \%)であった。この成績は既知の報告 $[3,5,7]$ とくら べて抙色なかった。以下に主な死亡例を示す。

低体温：摘出直後からの哺育温度を $27 \pm 2{ }^{\circ} \mathrm{C}$ とした 群では, 11匹中 4 匹が $1 \sim 7$ 日令時に死亡した。この温 度は今村（第17回実験動物談話会，1970）および唐沢ら

（第 5 回実験動物研究発表会, 1970）の用いた $30 \sim 28^{\circ} \mathrm{C}$ よりもわずかに低い程度であったが，体が冷たくなり， 下腹部が青黒くチアノーゼを呈して死亡する仔ウサギが 珰められた。一方室温を conventional ウサギの繁殖室 と同温度の $22 \pm 2{ }^{\circ} \mathrm{C}$ と, フロアヒーターで保温した 群では, このような死亡例はなく, 死因は体温の低下に よるものと考えられた。しかし室温は低くても，床温度 が高ければ体温は保持されるとみてよい。

肺炎: 乳汁の誤领が原因とみられる肺炎によって, 摘 出した 32 匹中 3 匹が 8 〜 13日令時に死亡した。いやがる 仔ウサギに無理に授乳する [1]，あるいは飲ませすぎる [3] と誤领するとの報告があるが，著者らの経験では， 仔ウサギはとくにいやがることもなくよく飲み，また乳 汁を吐出することもなかった。肺炎による死亡例は，哺 乳びんのゴム製乳首にあけた穴が大きすぎた場合に認め られたことから，仔ウサギが飲みこめる以上に乳汁が出 て誤飲したと考兄られた。

出血性盲腸炎：食欲, 䔬便など外見的に異常のないウ サギが，突然黒褐色下㢉便を排出して死亡した例がある が，それは離乳後まもない40〜80日令時に多発した。摘 出した 32 匹中 5 匹に発症し, 症状および剖検所見はウサ ギの出血性盲腸炎 $[4,6]$ と酷似していた。原因として腸 


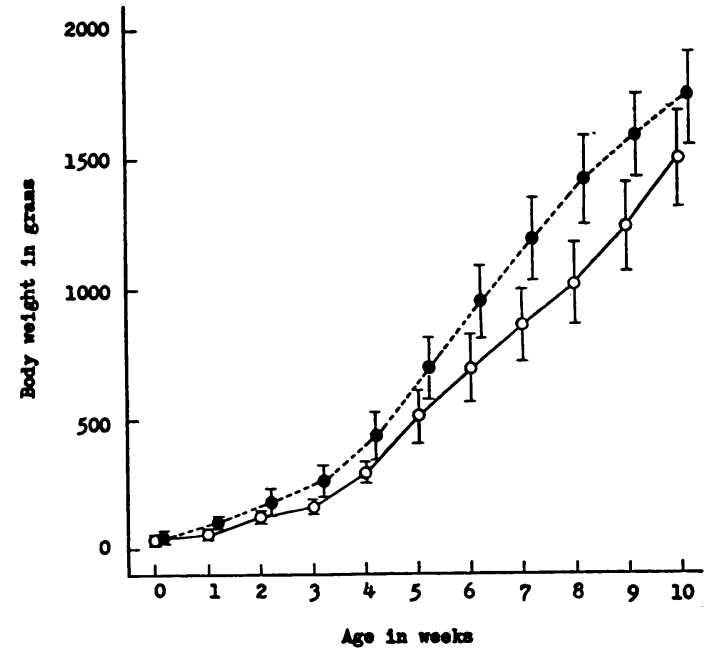

Fig. 1. Growth curves of hand-reared and conventional breast-fed rabbits.

Each value shows average and standard deviation of 6 hand-reared $(\bigcirc-\bigcirc)$ and 84 conventional (O.....) rabbits.

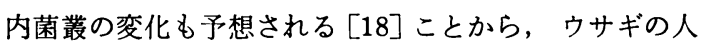
工哺育にあたっては, 適当な菌株の投与を考慮すべきか もしれない。

7. 成長：人工哺育ウサギと母ウサギ哺育のウサギの 体重曲線を Fig. 1 に示した。人工哺育ウサギの成長は, 母ウサギ哺育ウサギにくらべやや劣っていた。

仔ウサギの成長に関して Appel ら[1]は，ウサギ乳 を用いた場合, 人工哺育と母ウサギ哺育とに大差はない と述べている。一方村田ら［5]は市販小動物用粉乳を基 礎として調製した人工乳を用いた場合，母ウサギ哺育よ り成長がかなり劣っていたといら。これらの人工哺育は いずれもアイソレーター内でおこない 1 日 1 回授乳であ
るが，著者らはアイソレーターは用いず 1 日 2 回授乳に よった。このように飼育条件ならびに供試人工乳が異な るため，単純に比較することはできないが，混合乳によ る成長はウサギ乳より劣るが人工乳より勝っているとい えよう。両者を混合して授乳することの利点はここにあ る。

稿を終るにあたり，ウサギの飼育および管理にご協力いただ いた, 当センターの鈴木和美および河村啓由の両氏に心から感 謝する.

\section{文献}

[1] Appel, K. R., Busse, H., Schulz, K. D. und Wilk, W., (1971). Beitrag zur Handaufzucht von gnotobiotischen und SPF-Kaninchen. Z. Versuchstierk. 13 S, 282-290.

[2] Bernard, E. (1962). Methods and problems concerned with hand-rearing rabbits. J. Anim. Tech. Ass., $13,35-40$.

[3] Eveleigh, J. R. and Pease, S. S. (1976). The establishment of a breeding nucleus of category 4 dutch rabbits. Laboratory Animals, 10, 297-303.

[4] Kruijt, B. C. (1976). Enteritis in a conventional rabbit colony. Laboratory Animals, 10, 189-194.

[5] 村田行夫, 外田 檍, 杉本真次, 佐藤未知子, 勝俣是五郎 (1977). 市販人工粉乳を利用したウサギ新生仔の人工哺育 法。実験動物, 26, 23-28.

[6] Nikkels, R. J., Mullink, J. W. M. A. and Van Vliet, J. C. J. (1976). An outbreak of rabbit enteritis : Pathological and microbiological findings and possible therapeutic regime. Laboratory Animals, 10, 195 -198 .

[7] Scher, S., Collens, G. R. and Weisbroth, S. H. (19 69). The establishment of a specific-pathogene-free rabbit breeding colony. I. Procedures for establishment and maintenance. Lab. Animal Care, 19, 610616 .

[8] Whitney J. C. (1976). A review of nonspecific enteritis in the rabbit. Laboratory Animals, 10, 209-221.

［9］吉田 勉(1972). 無菌ウサギの人工哺育について. 実験動 物, $21,1-12$. 